\title{
BUREAUCRACY AND CORRUPTION IN PUBLIC SECTOR ACCOUNTING
}

Luminița IONESCU, Associate prof. Ph.D.

Spiru Haret University, Bucharest e-mail: luminita.ionescu@ spiruharet.com

Florentin CALOIAN, Lecturer PhD

Academy of Economic Studies, Bucharest

e-mail: florentin_caloian@yahoo.com

\begin{abstract}
Bureaucracy and corruption represent major causes of fiscal crises, and structural unemployment all over the world. According to WEF 2014 Global Risk Report, the bureaucracy has a high level in European countries and appreciation is growing that high historical rates of economic progress, especially those experienced by emerging markets, may not be sustainable in the future.

Corruption is growing in a changing global environment and is considered one of the most important geopolitical risks. Most of the time, corruption is associated with fraud and money laundering. European growing cities and public administration have a strong influence over bureaucracy in public sector accounting and more time to process the accounting and fiscal information.
\end{abstract}

Keywords: corruption, government, fraud, bureaucracy

JEL Classification: $\mathrm{D}_{72}, \mathrm{H}_{11}, \mathrm{H}_{26}, \mathrm{M}_{41}$

\section{Introduction}

This paper seeks to present some aspects of bureaucracy and corruption in the public administration, modern trends of bureaucracy and how corruption is related to bureaucracy, in the context of shadow economy. Bureaucracy refers to the administrative system governing any large institution and many public servants who are sorting different forms and papers. In the last years, we can observe a new form of bureaucracy, bureaucracy in European Union and many European regulations for public administration in the EU member states.

Romania has a bureaucratic system, like many other European countries, with bad consequences over the business climate and not encouraging investors. We consider that the bureaucratic Romanian system is a legacy from the communist regime before 1990 and also developed by the European directives. 


\section{Literature review}

The paper has based its conclusions on the researches from the last few years: Francu, L.G. and Paicu, C.L. (2008), The Romanian Bureaucratic System of the Public Administration, who presented how the bureaucratic system from Romania still creates a lot of artificial jobs. They think that those jobs are created to offer something to work to certain persons or not to fire others in the same position. For example, a job is created or a task is divided between two employees (two employees with one responsibility) for both of them to have a job. In this case, we can discuss about a suffocating bureaucracy. For someone "who must get certain documents being forced to wait in line in front of three or four desks or offices for stamps, deposit and petitions. In one place petitions apply, in another they are approved and somewhere else they take signatures and stamps but it is possible to wait in two places for the last two. In a way those who work in that system are helped but the state must pay their salaries, which implies further costs for the institution. People who get in contact with this system have their loss by being forced to run from one place to another" (Francu, L.G. and Paicu, C.L. 2008).

Popescu, I. (2011) in The Expansion of European Bureaucracy explained how descriptions and complaints about bureaucracy in the EU are numerous, but the supra-national bureaucracy is not exactly replicating the national one. He thinks that European Commission enjoys powers and privileges that no national bureaucracies have, and secondly, it is far too small to directly manage 500 million people. Also, the Brussels bureaucracy is largely dependent on the national administration and European administration is multilevel the same as its governance. "The interaction between the two national and supranational levels is said to have led to a merger of administrations (Wessels, 1997, p. 170), thus fueling the Weberian thesis on bureaucracy from a particular perspective" (Popescu, I., 2011). He discovered that European political construction reminds us of the premodern state building - based on some kind of bureaucracy that is "commissarial management", a term that highlights not only the administrative actions "strictosenso" but also and a political mission: an EU more integrated. Also, once the central bureaucracy is established, is often tends to decentralize power to agencies more or less independent for effective governance.

Uslaner, E.M., (2008) in his work Corruption, Inequality, and the Rule of Law: The Bulging Pocket Makes the Easy Life shows how corruption is persistent; there is little evidence that countries can escape the curse of corruption easily - or at all. He presented the rocky road to transition: the case of Romania. For many European transition countries, a key measure of success is admission to the European Community, but with great sacrifices from the new members. Since transition, Romania has made considerable progress in many respects, yet ordinary citizens are far from convinced that theirs lives are better. He noticed that citizens fault both democracy and the market and link these failures of liberal democracy to rising inequality and to continuing corruption. He observed how perception of rising inequality and of high-level of corruption lead to less trust in other people and low levels of trust also lead people to see more corruption. 


\section{Bureaucracy in public administration}

In the last years, we noticed growing bureaucracy in the public administration due to the weak institutions of EU member states. According to WEF 2014, demographic trends have been flagged, including the risk of being unable to deal with rapid population growth and the growing burden of an ageing population which could also be a source of great opportunities for society and business if managed effectively. Bureaucracy is related to unmanaged migration flows, overpopulation and energy crises. The growing complexity of today's interconnected world reduces the ability to make well-informed decisions, leading to a loss of responsibility (WEF - Global Risk Report, p. 27).

We present the causes and effects of bureaucracy in the figure no. 1:

Figure no. 1. Causes and effects of bureaucracy

Causes

Effects

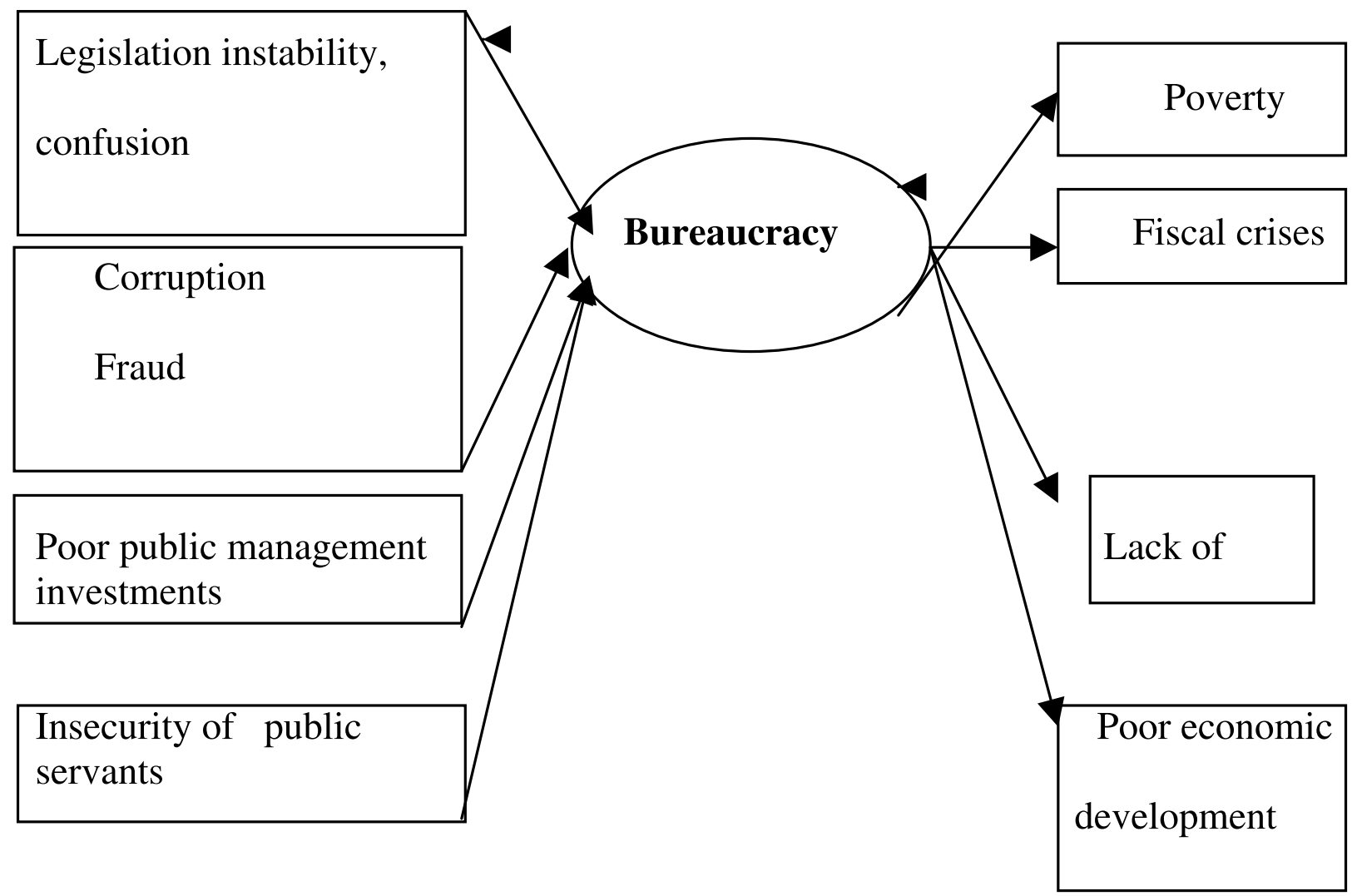

Source: Ionescu, L., Postdoctoral Research, Romanian Academy, 2012.

We consider that bureaucracy is a cause of poor economic development and is increasing the costs of public sector accounting in Romania. We would like to mention the big number of reports and accounting forms that the Romanian accountants must to fill and prepare for the accounting, but most clear reporting purpose. According to the accounting regulation, the public institutions in Romania must to prepare financial statements every quarter, but the private entities should 
prepare just twice a year, end of June and end of December. In this case, the public sector accounting is facing a big volume of work, waste of paper, power and other resources, plus the work of the accountants to prepare these forms. We suggest that would much efficient for the Romanian public sector if the financial statements would be prepared just once a year, at the end of the fiscal year, thus the financial information could be correct and complete for the public management and the managements decisions would be efficient.

In the last five years, there are some efforts from the government to reduce the level of the Romanian bureaucratic system some improvements. For example, National Agency for Fiscal Administration (ANAF) has implemented a fiscal system to allow all the companies and public institutions to send the fiscal forms and reports by Internet, using the electronic signature. ANAF has an important mission to provide the resources for the public administration by collecting and managing efficiently the taxes, charges, contributions and other amounts due to the general consolidated budget. ANAF will improve the relationship between institution - taxpayer and taxpayer - institution by which the new requirements of the citizen are replied to in its double role of user and beneficiary.

\section{Corruption in public administration}

It is well known that corruption is one of the most important causes of poverty and fiscal crises in EU. According to WEF 2014, the geopolitical category covers the areas of politics, diplomacy, conflict, crime and global governance. The disputes over resources, terrorism and war to governance could cause corruption, organized crime and illicit trade.

We consider that is a strong link between bureaucracy and corruption in public administration and public sector accounting. When bureaucracy became complex, quiet corruption is growing.

Quiet corruption has non-negligible long-term consequences, manifesting itself differently according to the nature of service delivery. The fight against quiet corruption requires tailoring policies to country circumstances. Fighting quiet corruption is critical if governments want to reduce poverty and promote sustainable growth. Quiet corruption is less likely to attract public attention. Corruption becomes an unavoidable element of daily life for many citizens. Quiet corruption can affect incentives and distort the allocation of resources. Corruption is generally ubiquitous and inevitable. Enterprises do not always bear the ultimate burden (they can often pass on any increased costs to consumers). Corruption is a major impediment to firm operations and growth (it manifests differently in each economic sector). Quiet corruption can lead to substantial long-term impacts on poverty. The fight against quiet corruption requires tailoring policies to country circumstances. (The World Bank, 2010) Greater prosecutor resources result in more convictions for corruption. The expected costs of engaging in corruption rise with the risk of being caught and prosecuted. Vastly increased resources to combat corruption would be internalized by potential perpetrators. Using higher government wages as an incentive can lower corruption. No one has investigated 
the loss of income suffered by those convicted of corruption offenses. Divided government is associated with lower corruption. Enforcement resources relative to population has a positive effect on convictions for corruption. Term limits appear to be associated with higher corruption. (Alt and Lassen, 2010)

Corruption leads to less trust in other people and to more inequality. Societies are trapped in a cycle of high inequality, low out-group trust, and high corruption. An unfair legal system is one of the key determinants of corruption. There are plenty of exceptions to treating corruption as violations of transparency. Petty corruption helps a large number of people cope with broken public and private sectors, and does not engender jealousy and mistrust. People make a clear connection between inequity and grand corruption (grand corruption troubles people far more than petty misdeeds). Petty corruption drags ordinary people into the web of dishonesty. High inequality leads to low out-group trust and then to high corruption. The fairness, not the effectiveness, of the legal system shapes corruption. The links from inequality to trust and from trust to corruption are strong. Corruption leads to public policies that produce better quality of life, stronger market performance, and less inequality. Grand corruption leads to social strains and to perceptions of rising inequality. Working from the ground up will not alleviate people's concerns about corruption. Corruption is part of an inequality trap that saps people of the belief that it is safe to trust others, transfers resources from the mass public to the elites, and is not easy to eradicate if it is largely based upon the distribution of resources and a society's culture. An unfair legal system is a key determinant of corruption (strong institutions, most notably equal justice for all, play a key role in combating corruption). Authoritarian governance generally leads to high levels of corruption. Inequality, low trust, and corruption form a vicious cycle. Reducing inequality frees people from being dependent upon corrupt patrons. Corruption rests upon a foundation of strong in-group trust and low outgroup trust. Uneven economic development is strongly related to all of the other determinants of corruption. Perceptions of corruption are higher in countries that have higher levels of economic inequality. People perceive a link between corruption and inequality. (Uslaner, 2008, 5-29)

Corruption in the public sector is related to bribery and money laundering. OECD presented in 2006 the most vulnerable activities for corruption and bribery: 


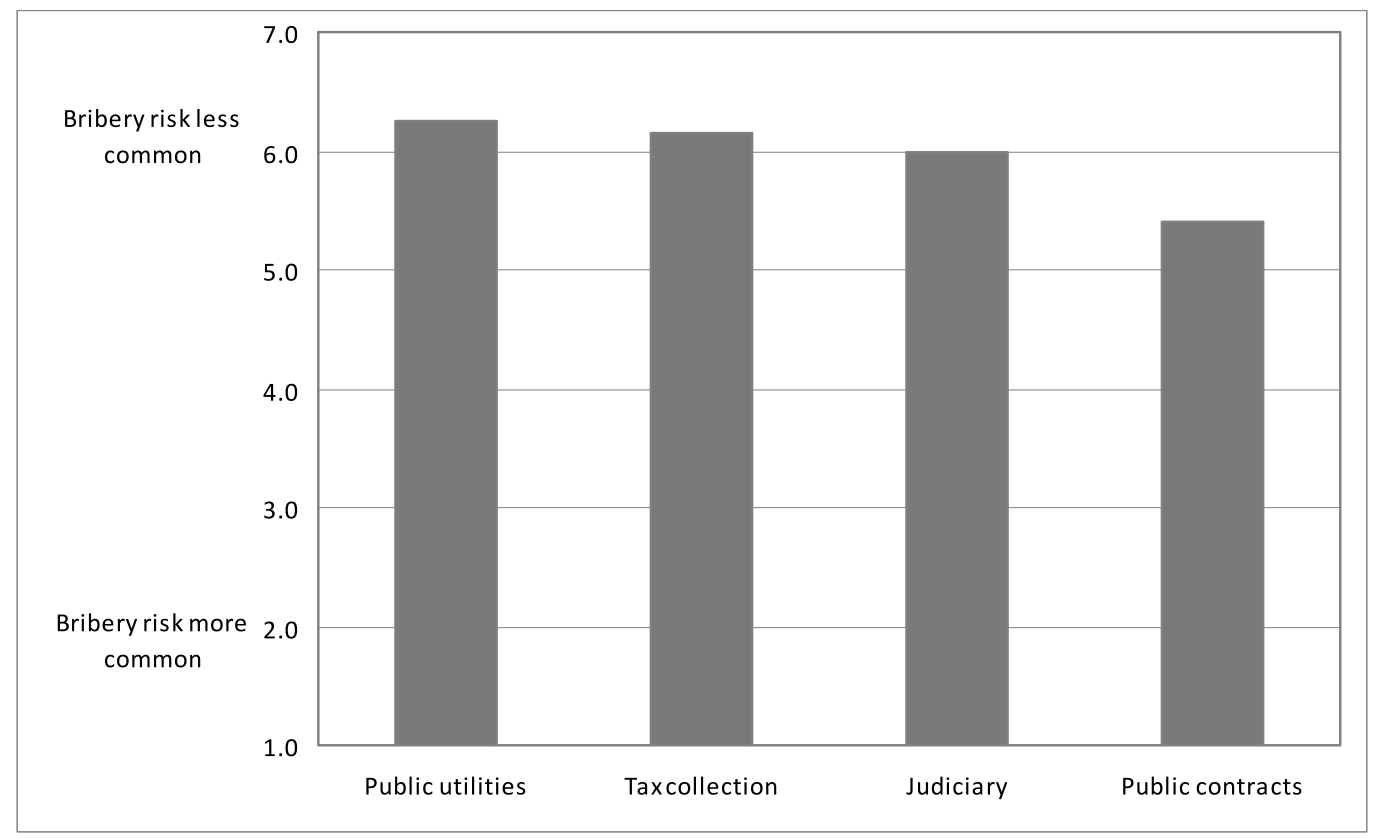

Figure no. 2. Average perceived level of bribery risk in selected government activities in OECD countries

Source: http://www.oecd.org/gov/ethics

In public sector accounting corruption is related to growing bureaucracy, lack of personnel and confusion due to the often changing legislation. A new case of corruption in the public sector accounting is related to the EU Structural Funds absorption and how these funds where spent in the public sector. These new issues in corruption affect central administration and local administration as well, including EU Structural Funds absorption (Zaman, G. and Cristea, A. 2011), and could involve a big number of persons, from a simple clerk to the general manager. In 2012-2013 EU suspended some payments for operational programs in Romania because of suspicious funds in the public sector and how these programs where implemented. Unfortunately, Romania has the poorest absorption rate among all the EU Member States and the worst among the ten new Member States. Moreover, the financial corrections, which amount to roughly $22 \%$ of the assimilated European funds, further reduce the real absorption rate, a loss that can be attributed entirely to corruption and mismanagement (Dimulescu et al 2013).

\section{Conclusion}

Bureaucracy became more important in European countries in the last decades with negative consequences public sector administration and public sector accounting. The enlargement of the EU and continuing changing legislation for the EU member states determined an increasing bureaucracy and new procedures difficult to follow and implement. In Romania, public administration must to find solutions for new accounting regulations and EU directives, but also for the private sector in order to encourage investments and funding. 
There is a link between corruption and bureaucracy in the public sector accounting, in our opinion corruption is a cause of bureaucracy, but also bureaucracy is a cause of increasing corruption. We observed how bureaucracy determined the poorest absorption of EU Structural Funds. In our opinion, bureaucracy could be reduced using the media and information systems and modern communication. In order to develop a modern EU zone, all the member states must to rely on new type communication channels and an innovation policy opened for the European consumer (Gârdan and Geangu, 2013).

\section{REFERENCES}

1. Alt, J.L. and Lassen, D.D. (2010), Enforcement and Public Corruption: Evidence from US States, EPRU Working Paper Series, 08.

2. Chaikin, D. and Sharman, J.C. (2009), Corruption and Money Laundering: A Symbiotic

Relationship, New York: Palgrave Macmillan, p. 45.

3. DiRienzo, C. et al. (2007), Corruption and the Role of Information, Journal of International Business Studies 38: 320-332.

4. Dimulescu, V. (2013), Risks of corruption and the management of EU funds in Romania, Romanian Journal of Political Science, Vol. 13, no. 1, Bucharest.

5. Francy, L.G. and Paicu, C.L. (2008), The Romanian Bureaucratic System of the Public Administration, Analele Universitatii din Oradea, Vol. 2, 2008.

6. Gârdan, D.A. and Geangu, I.P. (2013), Peculiarities of Marketing Communications in Cultural Marketing, Annals of Spiru Haret, Economic Series, Vol. 4(13), Issue 3.

6. Ionescu, L. (2012), Principles and Hypothesis on Bureaucracy and Corruption Phenomena, Postdoctoral Research, Romanian Academy, Bucharest.

7. Olsen, W. P. (2010), The Anti-Corruption Handbook. How to Protect Your Business in the Global Market Place, John Wiley \& Sons, Inc., Hoboken, New Jersey.

8. Popescu, I. (2011), The Expansion of European Bureaucracy, CES Working Papers, Vol. II.

9. Treisman, D. (2000), The causes of corruption: a cross-national study, Journal of Public Economics, 76.

10. Uslaner, E.M. (2008), Corruption, Inequality, and the Rule of Law: The Bulging Pocket Makes the Easy Life. New York: Cambridge University Press.

11. Zaman, G. and Cristea, A. (2011), EU Structural Funds Absorption in Romania: Obstacles and Issues, Romanian Journal of Economics, Volume 32, nr. 2, pp. 60-77.

12. http://www.weforum.org/issues/global-risks World Economic Forum 2014 Global Risk Report.

13. http://www.anaf.ro/ - Misiune ANAF. 